\title{
Contemporary trends in toxicological research on arsenic
}

\author{
Hermann M. Bolt ${ }^{1}$ · Jan G. Hengstler ${ }^{1}$ \\ Received: 4 September 2018 / Accepted: 13 September 2018 / Published online: 22 September 2018 \\ (c) Springer-Verlag GmbH Germany, part of Springer Nature 2018
}

\section{Introduction}

Historically, arsenic has played an eminent role in human poisoning (Bolt 2012; Nepovimova and Kuca 2018). Nowadays, a major environmental focus is on nutritional arsenic exposure by drinking water and food, world-wide (GundertRemy et al. 2015; Hettick et al. 2015; Medina-Pizzali et al. 2018). Against this background, the number of research articles on arsenic toxicity has increased steadily, which has led to several editorials in Archives of Toxicology (Golka et al. 2010; Bolt and Stewart 2010; Bolt 2012, 2013, 2015). The continuous peer review process of manuscripts published within the last 2-3 years in our journal has provided insights into current research trends, which are highlighted below.

\section{Effects of pre- and post-natal exposure to arsenic}

A field of high research interest are effects of human preand postnatal exposure to arsenic. For instance, Gliga et al. (2018) studied 9-year-old children from a longitudinal mother-child cohort in rural Bangladesh $(n=551)$. Prenatal and concurrent exposures to As were assessed via concentrations in maternal urine at gestational week 8 and in the urine of children at 9 years. In multivariable-adjusted linear regression models, prenatal As (natural log-transformed), but not children's concurrent urinary As, was positively associated with IGFBP3 concentrations $(\beta=76,95 \%$ CI 19 , 133). DNA methylation analysis revealed $\mathrm{CpGs}$ associated with both prenatal As and IGFBP3. Prenatal exposure to As was positively associated with IGFBP3 concentrations in children at 9 years, independent of IGF1. It was suggested

Hermann M. Bolt

bolt@ifado.de

1 IfADo, Leibniz Research Centre for Working Environment and Human Factors, TU Dortmund, Ardeystr. 67,

44139 Dortmund, Germany that this association may be, at least in part, epigenetically mediated.

Experimentally, attention has been given to alterations in learning and behavioural alterations. For instance, gestational exposure of mice to inorganic $\mathrm{As}^{3+}$ may alter glutamate disposition in the mouse hippocampus and ionotropic glutamate receptor expression, which has been linked to memory impairment in the offspring (Nelson-Mora et al. 2018).

Another focal point is an association between prenatal arsenic exposure and development of diabetes mellitus (v.i.). Recent experimental evidence in mice shows that prenatal arsenic exposure may impair glucose metabolism in the offspring in a sex-specific manner, which may be counteracted by folate/B12 supplementation (Huang et al. 2018).

Rahman et al. (2017) published a systematic review on early-life arsenic exposure in children. Studies on arsenic exposure and morbidity showed an increased risk of respiratory tract infections and diarrhoea. Findings of different studies on arsenic exposure and foetal, infant, and child growth were heterogeneous. Arsenic exposure was not associated with foetal growth, but there was limited evidence of negative associations between arsenic exposures and birth weight and growth during early childhood.

\section{Diabetes mellitus}

Environmental exposure to inorganic arsenic has a negative effect on glucose homeostasis, leading to diabetes mellitus. Experimental studies have pointed to some mechanisms underlying the diabetogenic effects, including (1) inhibition of insulin signalling (leading to insulin resistance) in glucose metabolising peripheral tissues; (2) inhibition of insulin secretion by pancreatic $\beta$ cells; (3) dysregulation of the methylation or expression of genes involved in maintenance of glucose or insulin metabolism and function and (4) impaired glucose homeostasis by hepatic metabolism of glycogen (Zhang et al. 2017; Dover et al. 2018). 
Inorganic $\mathrm{As}^{3+}$ is methylated in the brain by arsenic(III)methyltransferase (As3mt) in a process that requires glutathione. Susceptibility to toxic effects of inorganic arsenic depends, in part, on this methylation. As3mt-knockout (KO) mice cannot efficiently methylate $\mathrm{As}^{3+}$, and this is associated with an adverse metabolic phenotype that is characterised by obesity and insulin resistance. The extent of this impairment depends on sex and As exposure (Douillet et al. 2017).

\section{Other targets of arsenic toxicity}

Knockout of Asw3mt in mice also leads to consequences in phospholipid metabolism with a likely impact on the central nervous system (Huang et al. 2016).

A classical matter of research is the role of oxidative stress in As-induced toxicity (e.g. renal toxicity; Gong et al. 2016) and carcinogenicity (Bach et al. 2016). This is further investigated with regard to associated gene expression changes.

A field study was conducted by Fujihara et al. (2016) in a Vietnamese population exposed to elevated As levels in the drinking water. Associations of four single-nucleotide polymorphisms (p.Arg194Trp, p.Arg280His, p.Pro206Pro, and p.Arg399Gln) in X-ray repair with urinary arsenic metabolites and 8-hydroxy-2'-deoxyguanosine (8-OHdG) were studied. Individuals with genotype AA in p.Pro206Pro showed significantly higher urinary monomethylarsonic acid (MMAV) and lower dimethylarsinic acid (DMAV)/MMAV ratio than genotype AG. As for p.Arg399Gln, both Arg/Arg homozygous subjects and $\mathrm{Arg} / \mathrm{Gln}$ heterozygous individuals showed a significantly higher urinary inorganic As concentration and lower 8-OHdG concentrations than Gln/Gln homozygous individuals. The results suggested Arg399Gln to be a functional SNP that may be related to DNA repair activity.

The skin is a primary target of As carcinogenesis and toxicity, which calls for development of refined experimental models (Weinmueller et al. 2018). Skin hyperpigmentation is the most sensitive objective symptom in patients with arsenicosis. However, there is only limited information on the mechanism of arsenic-mediated skin hyperpigmentation. Now, results of Yajima et al. (2017) suggest that interaction between keratinocytes and melanocytes in the skin through ET-1 and its receptor contributes to the characteristic arsenic-mediated skin pigmentation.

With regard to immunotoxicity, chronic arsenic exposure of women from drinking water has been related to changes in the transcriptome and methylome of CD4-positive T cells, both genome-wide and in specific genes, supporting the hypothesis that arsenic causes immunotoxicity by interfering with gene expression and regulation (Engström et al. 2017).

\section{Organoarsenic compounds/arsenolipids}

A rapidly developing field is research on organic arsenicals. Exposure of humans may occur, as compounds of this group can be applied in polymers and biomaterials (Tanaka et al. 2018). Aromatic organoarsenic compounds are even used in some countries as feed additives for livestock and in the poultry industry (Fei et al. 2018), and arsenic-containing hydrocarbons may be present in fish and edible algae (Müller et al. 2018a, b). As organic arsenic compounds tend to accumulate in the brain, current interest is focussed on potential neurotoxicity and its mechanisms (Masuda et al. 2017; Witt et al. 2017). Arsenobetaine, which is the major water-soluble organoarsenic compound in fish, exerts no toxicity to humans (Borak and Hosgood 2007).

Arsenolipids can be classified into four groups (Witt et al. 2017): arsenic-containing fatty acids (AsFAs), arsenic-containing hydrocarbons (AsHCs), arsenosugar-phospholipids (AsPLs) and trimethylarsenic fatty alcohols (TMAsFOHs). AsFAs may occur esterified in triglycerides.

A substantial neurotoxic potential is ascribed to AsHCs. Members of this group easily cross the blood-brain barrier, and even at sub-toxic concentrations these may lead to barrier disruption. Thus, the hypothesis has been advanced that these could facilitate the transfer of accompanying foodborne toxicants into the brain (Müller et al. 2018a). AsHCs are biotransformed to a considerable extent. Identified metabolites formed in vitro include respective thioxoanalogues and As-containing fatty acids and fatty alcohols (Müller et al. 2018b).

\section{Final remark}

Progress reached within the last few years demonstrates that arsenic research is a vital contemporary focus in both epidemiological and experimental toxicology, encompassing a wide methodological horizon. Relevant submissions to Archives of Toxicology covering this field are therefore further invited.

\section{Compliance with ethical standards}

Conflict of interest The authors declare that they have no conflict of interest. 


\section{References}

Bach J, Peremartí J, Annangi B, Marcos R, Hernández A (2016) Oxidative DNA damage enhances the carcinogenic potential of in vitro chronic arsenic exposures. Arch Toxicol 90:1893-1905

Bolt HM (2012) Arsenic: an ancient toxicant of continuous public health impact: from Iceman Ötzi until now. Arch Toxicol 86(6):825-830

Bolt HM (2013) Current research trends on arsenic toxicology. Arch Toxicol 87(6):925-926

Bolt HM (2015) Highlight report: critical evaluation of key evidence on health hazards in the general European population by exposure to arsenic. Arch Toxicol 89(12):2455-2457

Bolt HM, Stewart JD (2010) Arsenic: metabolism and transport mechanisms in human hepatocytes. Arch Toxicol 84(1):1-2

Borak J, Hosgood HD (2007) Seafood arsenic: implications for human risk assessment. Regul Toxicol Pharmacol 47:204-212

Douillet C, Huang MC, Saunders RJ, Dover EN, Zhang C, Stýblo M (2017) Knockout of arsenic (+ 3 oxidation state) methyltransferase is associated with adverse metabolic phenotype in mice: the role of sex and arsenic exposure. Arch Toxicol 91:2617-2627

Dover EN, Beck R, Huang MC, Douillet C, Wang Z, Kleit EL, Stýblo M (2018) Arsenite and methylarsonite inhibit mitochondrial metabolism and glucose-stimulated insulin secretion in INS-1 832/13 $\beta$ cells. Arch Toxicol 92:693-704

Engström K, Wojdacz TK, Marabita F, Ewels P, Käller M, Vezzi F, Prezza N, Gruselius J, Vahter M, Broberg K (2017) Transcriptomics and methylomics of CD4-positive T cells in arsenic-exposed women. Arch Toxicol 91:2067-2078

Fei J, Wang T, Zhou Y, Wang Z, Min X, Ke Y, Hu W, Chai L (2018) Aromatic organoarsenic compounds (AOCs) occurrence and remediation methods. Chemosphere 207:665-675

Fujihara J, Yasuda T, Iwata H, Tanabe S, Takeshita H (2016) Association of XRCC1 polymorphisms with arsenic methylation. Arch Toxicol 90:1009-1012

Gliga AR, Engström K, Kippler M, Skröder H, Ahmed S, Vahter M, Raqib R, Broberg K (2018) Prenatal arsenic exposure is associated with increased plasma IGFBP3 concentrations in 9-year-old children partly via changes in DNA methylation. Arch Toxicol 92:2487-2500

Golka K, Hengstler JG, Marchan R, Bolt HM (2010) Severe arsenic poisoning: one of the largest man-made catastrophes. Arch Toxicol 85(12):1485-1489

Gong X, Ivanov VN, Hei TK (2016) 2,3,5,6-Tetramethylpyrazine (TMP) down-regulated arsenic-induced heme oxygenase-1 and ARS2 expression by inhibiting Nrf2, NF- $\mathrm{KB}, \mathrm{AP}-1$ and MAPK pathways in human proximal tubular cells. Arch Toxicol 90:2187-2200

Gundert-Remy U, Damm G, Foth H, Freyberger A, Gebel T, Golka K, Röhl C, Schupp T, Wollin K-M, Hengstler JG (2015) High exposure to inorganic arsenic by food: the need for risk reduction. Arch Toxicol 89:2219-2227

Hettick BE, Cañas-Carrell JE, French AD, Klein DM (2015) Arsenic: a review of the element's toxicity, plant interactions, and potential methods of remediation. J Agric Food Chem 63(32):7097-7107

Huang MC, Douillet CC, Stýblo M (2016) Knockout of arsenic (+ 3 oxidation state) methyltransferase results in sex-dependent changes in phosphatidylcholine metabolism in mice. Arch Toxicol 90:3125-3128

Huang MC, Douillet C, Dover EN, Stýblo M (2018) Prenatal arsenic exposure and dietary folate and methylcobalamin supplementation alter the metabolic phenotype of C57BL/6J mice in a sex-specific manner. Arch Toxicol 92:1925-1937

Masuda T, Ishii K, Seto Y, Hosoya T, Tanaka R, Nakayama T, Iwasaki N, Shibata Y, Tamaoka A (2017) Long-term accumulation of diphenylarsinic acid in the central nervous system of Cynomolgus monkeys. Arch Toxicol 91:2799-2812

Medina-Pizzali M, Robles P, Mendoza M, Torres C (2018) Ingesta de arsenico: el impacto en la alimentación y la salud humana. Rev Peru Med Exp Salud Publica 35(1):93-102

Müller SM, Ebert F, Raber G, Meyer S, Bornhorst J, Hüwel S, Galla H-J, Francesconi KA, Schwerdtle T (2018a) Effects of arsenolipids on in vitro blood-brain barrier model. Arch Toxicol 92:823-832

Müller SM, Finke H, Ebert F, Kopp JF, Schumacher F, Kleuser B, Francesconi KA, Raber G, Schwerdtle T (2018b) Arsenic-containing hydrocarbons: effects on gene expression, epigenetics, and biotransformation in HepG2 cells. Arch Toxicol 92:1751-1765

Nelson-Mora J, Escobar ML, Rodríguez-Durán L, Massieu L, Montiel T, Rodríguez VM, Hernández-Mercado K, Gonsebatt ME (2018) Gestational exposure to inorganic arsenic (iAs3+) alters glutamate disposition in the mouse hippocampus and ionotropic glutamate receptor expression leading to memory impairment. Arch Toxicol 92:1037-1048

Nepovimova E, Kuca K (2018) The history of poisoning: from ancient times until modern ERA. Arch Toxicol. https://doi.org/10.1007/ s00204-018-2290-0 (epub ahead of print)

Rahman A, Granberg C, Persson L- $\AA$ (2017) Early life arsenic exposure, infant and child growth, and morbidity: a systematic review. Arch Toxicol 91:3459-3467

Tanaka j, Davis TP, Wilson P (2018) Organic arsenicals as functional motifs in polymer and biomaterials science. Macromol Rapid Commun. https://doi.org/10.1002/marc.201800205 (epub ahead of print)

Weinmueller R, Kryeziu K, Zbiral B, Tav K, Schoenhacker-Alte B, Groza D, Wimmer L, Schosserer M, Nagelreiter F, Rösinger S, Mildner M, Tschachler E, grusch M, Grillari J, Heffeter P (2018) Long-term exposure of immortalized keratinocytes to arsenic induces EMT, impairs differentiation in organotypic skin models and mimics aspects of human skin derangements. Arch Toxicol 92:181-194

Witt B, Meyer S, Ebert F, Francesconi KA, Schwerdtle T (2017) Toxicity of two classes of arsenolipids and their water-soluble metabolites in human differentiated neurons. Arch Toxicol 91:3121-3134

Yajima I, Kumasaka MY, Iida M, Oshino R, Tanihata H, Al Hossain A, Ohgami N, Kato M (2017) Arsenic-mediated hyperpigmentation in skin via NF-kappa B/endothelin-1 signaling in an originally developed hairless mouse model. Arch Toxicol 91:3507-3516

Zhang C, Fennel EMJ, Doulliet C, Stýblo M (2017) Exposure to arsenite and methylarsonite produce insulin resistance and impair insulin-dependent glycogen metabolism in hepatocytes. Arch Toxicol 91:3811-3821 